Biol. Proced. Online 2002;4:1-9

\title{
Use of an Anaerobic Chamber Environment for the Assay of Endogenous Cellular Protein-Tyrosine Phosphatase Activities
}

\author{
Li Zhu ${ }^{1}$ and Barry Goldstein ${ }^{1 *}$
}

${ }^{1}$ Dorrance H. Hamilton Research Laboratories, Division of Endocrinology and Metabolic Diseases, Department of Medicine, Jefferson Medical College. Thomas Jefferson University, Philadelphia, PA, 19107. USA.

* To whom correspondence should be addressed: Barry J. Goldstein, M.D., Ph.D., Director, Division of Endocrinology, Diabetes and Metabolic Diseases, Jefferson Medical College, Room 349, Jefferson Alumni Hall, 1020 Locust Street, Philadelphia, PA 19107-6799. USA. Phone: (215) 503-1272. Fax: (215) 923-7932. Email: Barry.Goldstein@mail.tju.edu

Submitted: March 26, 2002; Accepted: May 16, 2002; Published: June 11, 2002.

Indexing terms: signal transduction; cysteine; protein-tyrosine-phosphatase; oxidation-reduction.

\begin{abstract}
Protein-tyrosine phosphatases (PTPases) have a catalytic cysteine residue whose reduced state is integral to the reaction mechanism. Since exposure to air can artifactually oxidize this highly reactive thiol, PTPase assays have typically used potent reducing agents to reactivate the enzymes present; however, this approach does not allow for the measurement of the endogenous PTPase activity directly isolated from the in vivo cellular environment. Here we provide a method for using an anaerobic chamber to preserve the activity of the total PTPase complement in a tissue lysate or of an immunoprecipitated PTPase homolog to characterize their endogenous activation state. Comparison with a sample treated with biochemical reducing agents allows the determination of the activatable (reducible) fraction of the endogenous PTPase pool.
\end{abstract}

\section{INTRODUCTION}

Dozens of enzyme homologs in the protein-tyrosine phosphatase (PTPase) superfamily have been cloned and characterized over the past decade (1). The unifying structural feature among PTPases, is a conserved $\sim 230$ amino acid domain that contains the characteristic sequence motif, $(\mathrm{I} / \mathrm{V}) \mathrm{H} \underline{C} \mathrm{XAGXGR}(\mathrm{S} / \mathrm{T}) \mathrm{G}$, with the cysteine residue that catalyzes protein phosphotyrosine hydrolysis by the formation of a cysteinyl-phosphate intermediate (2). The catalytic cysteine residue must be present in an unconjugated, unoxidized state to carry out phosphotyrosine hydrolysis. Thus, cellular and environmental reactions that lead to the oxidation or modification of this site will effectively block the enzyme's catalytic activity and reduce the specific activity of the cellular PTPase pool $(2,3)$. Since alterations in the oxidation state of the catalytic cysteine within the cellular environment has profound effects on the PTPase specific activity, attention has recently been focused on how the redox state of the catalytic thiol is regulated in vivo. Crystallographic studies have shown that this thiol moiety is in spatial proximity to amino acid side chains adjacent to the enzyme active site that strongly affect its ionization (4). These interactions enhance the reactivity of the cysteine thiol group and effectively lowers its $\mathrm{pK}_{\mathrm{a}}$ to more than 3 units below that found in a typical free cysteine thiol or protein cysteine side chains. Thus, at physiological $\mathrm{pH}$, the catalytic cysteine is ionized as a thiolate anion which is easily derivatized or oxidized in preference to other neighboring sulfhydryls $(3,5)$.

One method to directly assess the reversible oxidation of thioldependent cellular enzymes, including PTPases, is to work under a neutral atmosphere. We have recently demonstrated that from a variety of tissue sources, PTPases are sensitive to oxidation by exposure to air when working with cell lysates on the benchtop (6). Frequently, reduction of the PTPases present in a cell lysate by biochemical treatment with strong reducing agents is incomplete, preventing an accurate assessment of both the endogenous level of PTPase activity, as well as the fraction of the PTPase pool that is reversibly oxidized or conjugated. Working within an anaerobic chamber allows for the measurement of endogenous PTPase levels, and including a biochemical reductant in the assay buffer allows for the measurement of the reducible pool of PTPase in the sample. This technique is useful for assay of cellular lysates or immunoprecipitated enzymes where specific antibodies are available.

\section{MATERIALS AND METHODS}

Cell culture media and sera were obtained from Cellgro

(c) 2002 Biological Procedures Online. Published in Biological Procedurs Online under license from the author(s). Copying, printing, redistribution and storage permitted. 
(Herndon, VA). Para-nitrophenylphosphate ( $p$ NPP) and reduced, carboxymethylated-maleylated (RCM)-lysozyme were obtained from Sigma. $\gamma-\left[{ }^{32} \mathrm{P}\right]$-ATP was from Amersham Pharmacia Biotech (Piscataway, NJ). Monoclonal PTP1B antibody (Ab-2) was from Calbiochem/Oncogene Sciences (La Jolla, CA). Trisacryl protein $G$ was obtained from Pierce (Rockford, IL). The BBL GasPak Disposable Anaerobic Indicator, \#4370504 was purchased from Becton Dickinson, (Sparks, MD). All other reagents were obtained from Sigma Chemical (St. Louis, MO) or Fisher Scientific (Pittsburgh, PA).

\section{Cell Culture}

3T3-L1 pre-adipocytes were maintained in Dulbecco's modified Eagle's medium (DMEM) / Ham's F12 medium (1:1) supplemented with $10 \%(\mathrm{v} / \mathrm{v})$ fetal calf serum. Adipocyte differentiation was induced at 2 days post confluence with medium supplemented with $100 \mathrm{nM}$ insulin, $0.25 \mu \mathrm{M}$ dexamethasone, and $0.5 \mathrm{mM}$ isobutylmethylxanthine (IBMX). After 2 days, dexamethasone and IBMX were removed from the medium and the cells were allowed to differentiate further for an additional 6 days. Prior to use, the cells were serumstarved in medium containing $0.1 \%(\mathrm{w} / \mathrm{v})$ bovine serum albumin (BSA) for 16 hours. Human HepG2 cells were maintained in Eagle's Minimal Essential Medium (EMEM) supplemented with $10 \%(\mathrm{v} / \mathrm{v})$ fetal calf serum and $1 \mathrm{X}$ each of non-essential amino acids and L-glutamine (Cellgro). Cells were used at $80 \%$ confluence, after 16 hours of serum starvation in medium containing $0.5 \%(\mathrm{w} / \mathrm{v}) \mathrm{BSA}$.

\section{Preparation of Cell Lysates}

Cells are lysed by homogenization in ice-cold homogenization buffer $(150 \mathrm{mM} \mathrm{NaCl}, 5 \mathrm{mM}$ EDTA, $5 \mathrm{mM}$ EGTA, in $50 \mathrm{mM}$ Hepes, pH 7.5, containing a protease inhibitor cocktail (Sigma), with brief sonication. Prior to use, all buffer solutions are deoxygenated within the chamber by stirring overnight.

\section{Anaerobic Chamber and Experimental Conditions}

An enclosed anaerobic work station (Forma Scientific, model \# 901024) was used to provide an oxygen-free environment for cell and tissue homogenization and anaerobic PTPase assay. The use of this chamber is detailed in the Protocol section. This chamber uses palladium catalyst wafers and desiccant wafers to maintain strict anaerobiosis to less than $10 \mathrm{ppm} \mathrm{O}_{2}$ (according to the specifications provided by the manufacturer). High purity $\mathrm{N}_{2}$ is used for purging the chamber initially and the working anaerobic gas mixture was $\mathrm{N}_{2}: \mathrm{H}_{2}: \mathrm{CO}_{2}$ proportioned at 85:10:5. Monitoring the $\mathrm{O}_{2}$ concentration to identify possible air leaks while working in the chamber is performed using a BBL GasPak Disposable Anaerobic Indicator which changes color when the $\mathrm{O}_{2}$ concentration reaches $0.5 \%(\sim 5000 \mathrm{ppm})$. For anaerobic conditions, the tissue samples and cultured cells were introduced into the chamber in a frozen state and disrupted as described above into deoxygenated homogenization buffers.
Following appropriate cell treatment with various hormones, cytokines or other reagents, the dish is snap-frozen by pouring on a layer of liquid nitrogen. Once the nitrogen has evaporated, the dishes are introduced into the chamber in a frozen state according to the detailed protocol discussed below.

\section{PTPase Enzyme Activity Using $p$ NPP as Substrate}

Aliquots containing an appropriate amount of cell fraction protein are incubated in a final volume of $100 \mu \mathrm{l}$ at $30^{\circ} \mathrm{C}$ for cell lysates or $37^{\circ} \mathrm{C}$ for immunoprecipitated enzymes, for 10$120 \mathrm{~min}$ in reaction buffer containing $10 \mathrm{mM} p \mathrm{NPP}$ and $2 \mathrm{mM}$ EDTA in $20 \mathrm{mM}$ 2-(N-morpholino)ethanesulfonic acid (MES) at $\mathrm{pH} 6.0$, with and without $2 \mathrm{mM}$ DTT. The reaction was stopped by the addition of $900 \mu \mathrm{l}$ of $0.2 \mathrm{M} \mathrm{NaOH}$ and the absorption was determined at $410 \mathrm{~nm}$ (7). The initial rate of $p$ NPP hydrolysis was estimated from the linear portion of the earliest time points of the enzymatic reaction.

\section{PTPase Enzyme Activity Using [ ${ }^{32}$ P]-RCM- Lysozyme as Substrate}

Alternatively, RCM-lysozyme can be used as a more specific PTPase substrate. Recombinant human insulin receptors from transfected $\mathrm{CHO}$ cells (8) or commercially available were partially purified on wheat germ lectin-agarose (Vector Laboratories, Burlingame, CA) as described (9). RCMlysozyme was radioactively labeled on tyrosine by phosphorylating with the insulin receptor preparation and $\gamma$ $\left[{ }^{32} \mathrm{P}\right]$-ATP (10). The reaction was initiated with the addition of $0.5 \mathrm{mg}$ of RCM-lysozyme and incubated at $25^{\circ} \mathrm{C}$ for $16 \mathrm{hrs}$. The reaction was terminated with the addition of trichloroacetic acid (TCA) to a final concentration of $20 \%(\mathrm{w} / \mathrm{v})$ and centrifuged at $30,000 \times \mathrm{g}$ for $15 \mathrm{~min}$ at $4^{\circ} \mathrm{C}$. The pellet was washed 3 times with $20 \%$ TCA and dialyzed against $50 \mathrm{mM}$ imidazole-HCl, $\mathrm{pH}$ 7.2.

PTPase activity was assayed using the indicated amount of cell fraction protein at $30^{\circ} \mathrm{C}$ for cell lysates or $37^{\circ} \mathrm{C}$ for immunoprecipitated enzymes, for $10-120 \mathrm{~min}$ in reaction buffer containing $50 \mathrm{mM}$ HEPES, pH 7.0 and $2 \mathrm{mM}$ EDTA, with and without $2 \mathrm{mM}$ DTT. The reaction was initiated by the addition of $20 \mu \mathrm{l}$ of $\left[{ }^{32} \mathrm{P}\right]$-phosphotyrosyl RCM-lysozyme $(\sim 20,000 \mathrm{dpm})$ and terminated by the addition of $0.9 \mathrm{ml}$ of acidic charcoal mixture, consisting of $0.9 \mathrm{M} \mathrm{NaCl}, 90 \mathrm{mM}$ sodium pyrophosphate, $2 \mathrm{mM} \mathrm{NaH} \mathrm{PO}_{4}$ and $4 \%$ (w/v) Norit A activated charcoal (11). After centrifugation in a microfuge, the amount of radioactivity in $0.4 \mathrm{ml}$ of supernatant was measured by Cerenkov counting in a liquid scintillation counter. The initial rate of RCM-lysozyme hydrolysis was estimated from the linear portion of the earliest time points of the enzymatic reaction where less than $20 \%$ of the RCM-lysozyme was hydrolyzed during the 30 minute reaction period. 


\section{RESULTS}

Assay of overall PTPase activity in cell or tissue lysates. We have evaluated this method using differentiated 3T3-L1 adipocytes. Cells were snap frozen with liquid nitrogen and transferred into the chamber for assay. Cells were lysed within the chamber environment into deoxygenated buffers and lysates were withdrawn from the chamber using tightly-capped sealed tubes for centrifugation. The enzyme assay was performed within the chamber using $p$ NPP as substrate.

Cell lysis on the benchtop under aerobic conditions resulted in a $27 \%$ reduction in PTPase activity $(\mathrm{P}<0.001)$ in the crude homogenates measured in the absence of added reducing agents (Fig. 1). When PTPase activity was measured in the presence of DTT, we detected no significant change in the activity as measured in the chamber. However, the activity that had been inhibited by air exposure was restored by treatment with DTT to the level found when samples were maintained in the anaerobic chamber (Fig. 1).

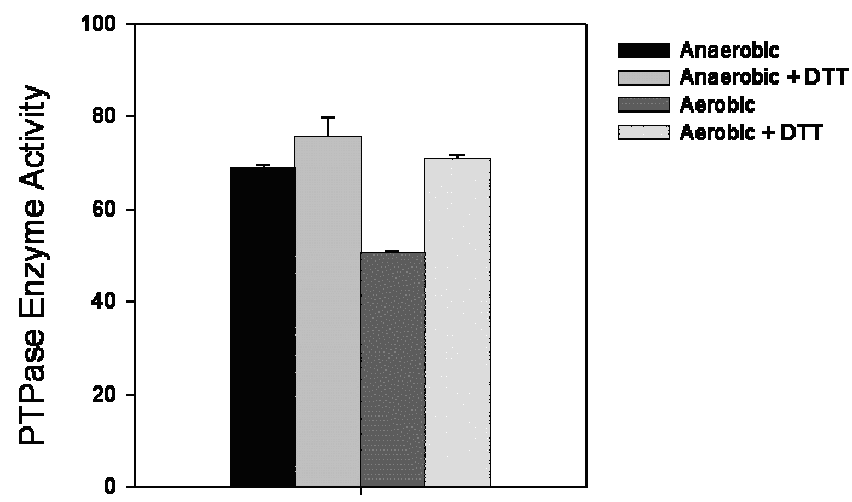

Fig. 1: Effect of air exposure on PTPase activity in lysates of 3T3-L1 adipocytes and reversibility with DTT. 3T3-L1 adipocytes were differentiated as described in Methods and individual $10-\mathrm{cm}$ dishes were snap-frozen with liquid nitrogen. Replicate dishes were then introduced into the anaerobic chamber in the frozen state and disrupted into deoxygenated buffers or homogenized into the same buffer on the bench top in air. Samples containing $30 \mu \mathrm{g}$ protein were then subjected to the $p$ NPP assay in the presence or absence of $2 \mathrm{mM}$ DTT as

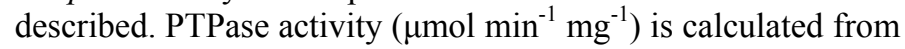
the $\mathrm{A}_{410}$ of the samples following a $10 \mathrm{~min}$ incubation using a molar extinction coefficient of $1.78 \times 10^{4} \mathrm{M}^{-1} \mathrm{~cm}^{-1}$ (7). Modified from reference 6 and reproduced with permission.

We also evaluated whether the catalytic activity of PTP1B, a specific cellular PTPase enzyme immunoprecipitated from HepG2 cells was altered by exposure to air (Fig. 2). The measurement of PTP1B-specific activity was facilitated by using a monoclonal antibody to PTP1B that can immunoadsorb the enzyme in a catalytically active state. To maintain the endogenous reduced state of the enzyme thiol, all stages of the immunoprecipitation process, including centrifugation, washing of the pellets, and the assay itself were performed under strict nonoxidizing conditions. The activity of PTP1B was reduced dramatically by air exposure to $36 \%$ of the level observed in the samples maintained under anaerobic conditions throughout the experiment within the chamber environment $(\mathrm{P}<0.001)$.

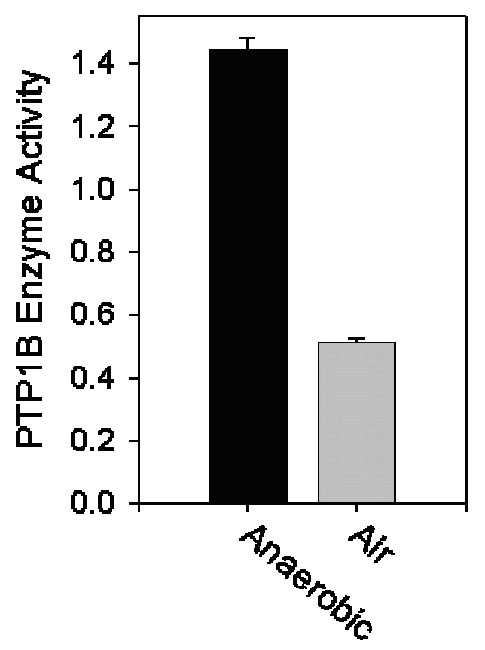

Fig. 2: Effect of air exposure and in vitro oxidation and reduction reactions on the catalytic activity of PTP1B. Following a preclearing step, PTP1B was immunoprecipitated from lysates of snap-frozen HepG2 cells either within the anaerobic chamber environment or on the bench top in air, as described in Materials and Methods. The immunoprecipitated samples were washed, and PTPase activity was assayed by using $p$ NPP as substrate. A comparison between PTP1B activity under aerobic vs. anaerobic conditions is shown. PTPase activity is presented as $\mu \mathrm{mol} \mathrm{min}^{-1} \mathrm{mg}^{-1}$ immunoprecipitated cell lysate. Modified from reference 6 and reproduced with permission.

\section{DISCUSSION}

PTPases are highly active enzymes with high turnover rates, and their activity in the cell must be attenuated for signal transduction mechanisms involving protein tyrosine phosphorylation to proceed in a balanced manner (12). Recently, several laboratories have provided evidence for novel regulatory mechanisms involving reactive oxygen species, especially $\mathrm{H}_{2} \mathrm{O}_{2}$, which can oxidize and inactivate PTPase enzymes in a stepwise fashion (13-15). The regulation of PTPase catalytic activity by reactions involving the catalytic cysteine is emerging as a key mode for suppression of these enzymes in signal transduction by hormones and cytokines in the cell (16-17).

This methodology can be used to assay the total PTPase activity in lysates of various cells and tissues from different sources as well as following treatments with hormones or cytokines. Cells are stabilized by snap-freezing with liquid 
nitrogen and transferred into the chamber for assay. Handling of the samples within the chamber can maintain the state of enzyme reduction and activation from the time of isolation. Samples can also be withdrawn from and reintroduced into the chamber keeping the samples within the confines of tightlycapped O-ring sealed tubes for various experimental manipulations, such as centrifugation or incubations with reagents that require refrigerated temperatures.

Sample assay in the absence or presence of added dithiothreitol provides a means of directly evaluating the proportion of endogenous enzyme activity that can be reactivated by biochemical reduction. The reactivated activity fraction represents enzyme forms that are partially oxidized by intracellular reactions with reactive oxygen species as well as artifactually by air exposure (Fig. 3).

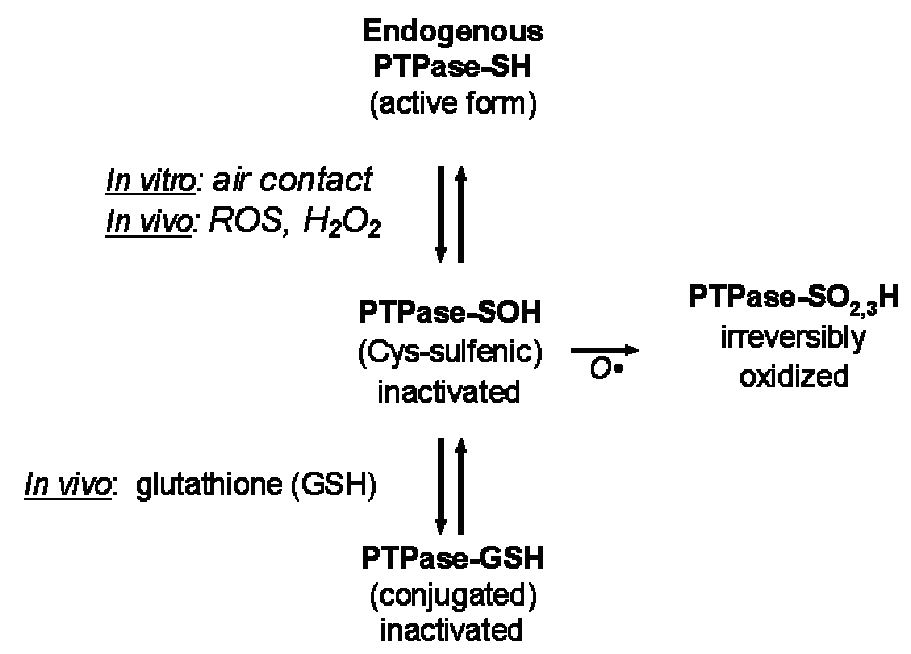

Fig. 3: Some oxidative structural modifications of the PTPase catalytic site that occur in vivo.

The catalytic thiol of PTPases is susceptible to a variety of inactivating modifications. These include oxidation in a stepwise fashion to progressively more inert forms (13-15). The catalytic cysteine thiol is first oxidized to the sulfenic (-SOH) form, which is amenable to reduction by cellular enzymatic mechanisms or with reducing agents in vitro, followed by further sequential steps of oxidation, to sulfinic $\left(-\mathrm{SO}_{2} \mathrm{H}\right)$ and sulfonic $\left(-\mathrm{SO}_{3} \mathrm{H}\right)$ forms, leading to irreversible PTPase inactivation. Also, the reduced, ionized cysteine thiol, or a partially oxidized form is susceptible to conjugation with glutathione, which provides an inactive, but potentially reactivatable form of the enzyme (22).

Our laboratory has been interested in studying PTPases, in particular characterizing their role in the regulation of the insulin action pathway (18). The intracellular PTPase PTP1B, has emerged as a key regulator of insulin signaling and is a target of inhibition for the potential treatment of type 2 diabetes mellitus (19). PTP1B is the target of an oxidant signal generated by the action of EGF and other growth factors (17). Insulin also generates a cellular oxidant burst that appears to be coupled to the oxidative inhibition of PTP1B in insulinsensitive cell types $(20,21)$.

In summary, we describe the use of a commercially available anaerobic chamber system to evaluate the endogenous level of PTPase activity from various cell and tissue sources (6). Since cellular PTPases, as well as other enzyme systems that may be susceptible to oxidation-reduction reactions, are susceptible to oxidative inhibition by air exposure, the use of the anaerobic chamber methodology provides an important advantage for enzyme characterization. Evaluation of the changes in the activation state of cellular PTPases from endogenous sources has recently provided additional evidence for modulation of the activation state of this important class of regulatory enzymes within the cellular milieu in response to changes in the abundance of cellular reactive oxygen species and other thiol side-chain reactions, including glutathione conjugation. This approach is widely adaptable to the characterization of regulation of thiol reactivity in determining the catalytic activity of cellular PTPases and how this process impacts on signal transduction by reversible protein-tyrosine phosphorylation.

\section{ACKNOWLEDGEMENTS}

We appreciate helpful discussions during the initiation of this work with Dr. Sue Goo Rhee, Chief, Laboratory of Cell Signaling, NHLBI, NIH. This work was supported by grants DK43396 and DK53388 from the NIH and a Mentor-based postdoctoral fellowship in support of $\mathrm{Dr}$. $\mathrm{Li} \mathrm{Zhu}$ to $\mathrm{Dr}$. Goldstein. 


\section{REFERENCES}

1. Tonks NK, Neel BG. Combinatorial control of the specificity of protein tyrosine phosphatases Curr. Opin. Cell Biol. 2001;13:182-195.

2. Zhang ZY. Protein-tyrosine phosphatases - biological function, structural characteristics, and mechanism of catalysis Crit. Revs. Bioch. Mol. Biol. 1998;33:1-52.

3. Den JM, Dixon JE. Protein tyrosine phosphatases mechanisms of catalysis and regulation Curr. Opin. Chem. Biol. 1998;2:633-641.

4. Barford D, Das AK, Egloff MP. The structure and mechanism of protein phosphatases - insights into catalysis and regulation Ann. Rev. Biophys. Biomol. Struct. 1998;27:133-164.

5. Lohse DL, Denu JM, Santoro N, Dixon JE. Roles of aspartic acid 181 and serine-222 in intermediate formation and hydrolysis of the mammalian proteintyrosine-phosphatase ptp1 Biochemistry 1997;36:4568-4575.

6. Zhu L, Zilbering A, Wu X, Mahadev K, Joseph JI, Jabbour S, Deeb W, Goldstein BJ. Use of an anaerobic environment to preserve the endogenous activity of protein-tyrosine phosphatases isolated from intact cells Published online as The FASEB Journal express article 10.1096/fj.00-0795fje. FASEB J. 2001;15:1637-1639.

7. Pot DA, Woodford TA, Remboutsika E, Haun RS, Dixon JE. Cloning, bacterial expression, purification, and characterization of the cytoplasmic domain of rat LAR, a receptor-like protein tyrosine phosphatase $J$. Biol. Chem. 1991;266:19688-19696.

8. Hashimoto N, Feener EP, Zhang WR, Goldstein BJ. Insulin receptor protein-tyrosine phosphatases Leukocyte common antigen-related phosphatase rapidly deactivates the insulin receptor kinase by preferential dephosphorylation of the receptor regulatory domain J. Biol. Chem. 1992;267:1381113814.

9. Pike LJ, Kuenzel EA, Casnellie JE, Krebs EG. A comparison of the insulin- and epidermal growth factor-stimulated protein kinases from human placenta J. Biol. Chem. 1984;259:9913-9921.

10. Tonks NK, Diltz CD, Fischer EH. Purification and assay of CD45: An integral membrane proteintyrosine phosphatase Meth. Enzymol. 1991;201:442451.

11. Streuli M, Krueger NX, Thai T, Tang M, Saito H. Distinct functional roles of the two intracellular phosphatase like domains of the receptor-linked protein tyrosine phosphatases LCA and LAR EMBO J. 1990;9:2399-2407.
12. Hunter T. Protein kinases and phosphatases: the yin and yang of protein phosphorylation and signaling Cell 1995;80:225-236.

13. Barrett WC, DeGnore JP, Keng YF, Zhang ZY, Yim $\mathrm{MB}$, Chock PB. Roles of superoxide radical anion in signal transduction mediated by reversible regulation of protein-tyrosine phosphatase 1B J. Biol. Chem. 1999;274:34543-34546.

14. Claiborne A, Yeh JI., Mallett TC, Luba J, Crane EJ, Charrier V, Parsonage D. Protein-sulfenic acids: Diverse roles for an unlikely player in enzyme catalysis and redox regulation Biochemistry 1999;38:15407-15416.

15. Barrett WC, DeGnore JP, Konig S, Fales HM, Keng YF, Zhang ZY, Yim MB, Chock PB. Regulation of PTP1B via glutathionylation of the active site cysteine 215 Biochemistry 1999;38:6699-6705.

16. Denu JM, Tanner KG. Specific and reversible inactivation of protein tyrosine phosphatases by hydrogen peroxide - evidence for a sulfenic acid intermediate and implications for redox regulation Biochemistry 1998;37:5633-5642.

17. Lee SR, Kwon KS, Kim SR, Rhee SG. Reversible inactivation of protein-tyrosine phosphatase $1 \mathrm{~B}$ in A431 cells stimulated with epidermal growth factor $J$. Biol. Chem. 1998;273:15366-15372.

18. Goldstein BJ. Protein-tyrosine phosphatases and the regulation of insulin action. In: LeRoith D, Olefsky JM, Taylor SI, editors. Diabetes mellitus: A fundamental and clinical text. 2nd edition., Philadelphia: Lippincott Press; 2000. p. 206-217.

19. Goldstein BJ. Protein-Tyrosine Phosphatase 1B (PTP1B): A Novel Therapeutic Target for Type 2 Diabetes Mellitus, Obesity and Related States of Insulin Resistance Curr. Drug Targets - Immune, Endocrine Metab. Dis. 2001;1:265-275.

20. Mahadev K, Zilbering A, Zhu L, Goldstein BJ. Insulin-stimulated hydrogen peroxide reversibly inhibits protein-tyrosine phosphatase $1 \mathrm{~B}$ in vivo and enhances the early insulin action cascade J. Biol. Chem. 2001;276:21938-21942.

21. Mahadev K, Wu X, Zilbering A, Zhu L, Lawrence JTR, Goldstein BJ. Hydrogen peroxide generated during cellular insulin stimulation is integral to activation of the distal insulin signaling cascade in 3T3-L1 adipocytes J. Biol. Chem. 2001;276:4866248669.

22. Sullivan DM, Wehr NB, Fergusson MM, Levine RL, Finkel T. Identification of oxidant-sensitive proteins: TNF-alpha induces protein glutathiolation Biochemistry 2000;39:11121-11128. 


\section{PROTOCOLS}

Annotated from Model 1025/1029 Anaerobic System Installation and Operation Manual, Manual No. 7011025, Revision 2, Forma Scientific, Inc., PO Box 649, Marietta, OH 45750.

\section{Anaerobic manipulation procedures}

\section{General information}

1. The anaerobic work station (model \#901024) was purchased from Forma Scientific, Marietta, OH.

2. High-purity $\mathrm{N}_{2}$ for purging and the working anaerobic gas mixture $\left(\mathrm{N}_{2}: \mathrm{H}_{2}: \mathrm{CO}_{2}=85: 10: 5\right)$ from a reliable commercial source.

3. The anaerobic environment inside the chamber should be monitored with $\mathrm{O}_{2}$ indicator strips (BBL strips, Becton Dickinson and company) prior to and during experiments. The strips will react if the ambient $\mathrm{O}_{2}$ concentration is more than $0.5 \%$ in the chamber.

4. Buffer solutions and equipment introduced into the chamber need to be deoxygenized overnight prior to use in experiments.

\section{$\underline{\text { Installation of charcoal, catalyst and desiccant activated wafers, and the chamber relief bubbler }}$}

1. Open the air filter system door in the top center of the right side wall.

2. Slide the wafers into the correct slots, charcoal on top, palladium catalyst wafer in the middle and desiccant wafer at the bottom.

3. The palladium catalyst wafers and desiccant wafers need to be regenerated by heating $160^{\circ} \mathrm{C}$ for two hours weekly, and can be reused for one year. The charcoal activated filter needs to be replaced every 6 months.

4. To prepare the chamber relief bubbler, fill the glass bottle shipped with the unit, with mineral oil to a level of approximately 1-1/2 inches. Clip the bottle into the chamber relief with the tubing extending approximately $1 / 8$ inches in the mineral oil.

5. Change the mineral oil once a month and clean the bottle. Check the bottle daily to ensure that the tube extends into the mineral oil.

Preparation of anaerobic environment for the first use, operation of the interchange device both automatically and manually, are performed exactly as described in the manual.

\section{Initial settings:}

1. Gas system switch $\rightarrow$ on.

2. Catalyst fan switch $\rightarrow$ on.

3. Light switch $\rightarrow$ on.

4. Vacuum, nitrogen, and equalize switch $\rightarrow$ auto.

5. Manual fill knob $\rightarrow$ off.

Deoxygenation of solutions:

1. Open the outer door with the inner door closed.

2. Put the solution in a baker with stir bar and other related material into the exchanger.

3. Close the outer door.

4. Press the start cycle button to run one or more degas cycles automatically or run manually.

5. Open the inner door and transfer the items into the glove chamber.

6. Close the inner door.

7. Put the baker on a stir plate overnight to equalize the solution.

8. Check for anaerobiosis with a BBL strip.

9. If the solution is anaerobic, aliquot in bottles with sealable cap, and transfer out of chamber.

10. Store the anaerobic solution in $4^{\circ} \mathrm{C}$. 


\section{Measurement of activities of PTP1B and PTPase of cultured cells under anaerobic environment}

\section{$\underline{\text { Cell Culture and cell differentiation }}$}

3T3-L1 cell culture and differentiation:

1. 3T3-L1 pre-adipocytes are maintained in Dulbecco's modified Eagle's medium (DMEM) / Ham's F12 medium (1:1) supplemented with $10 \%(\mathrm{v} / \mathrm{v})$ fetal calf serum. Never let the cells grow to confluence for passing or seeding.

2. Cells are seeded in $10 \mathrm{~cm}$ culture dishes and the medium is changed every other day.

3. When cells become confluent, change medium and let cells grow two more days.

4. Cell differentiation is induced at 2 days post confluence with medium supplemented with $100 \mathrm{nM}$ insulin, $0.25 \mu \mathrm{M}$ dexamethasone, and $0.5 \mathrm{mM}$ isobutylmethylxanthine (IBMX).

5. After 2 days, change medium with $100 \mathrm{nM}$ insulin every other day for an additional 6 days.

6. Prior to use, the cells are serum-starved in medium containing $0.1 \%(\mathrm{w} / \mathrm{v})$ bovine serum albumin (BSA) for 16 hours.

Human HepG2 cell culture:

1. Human HepG2 cells are maintained in Eagle's Minimal Essential Medium (EMEM) supplemented with 10\% (v/v) fetal calf serum and $1 \mathrm{x}$ each of non-essential amino acids and L-glutamine (Cellgro).

2. Cells are used at $80 \%$ confluence, after 16 hours of serum starvation in medium containing $0.5 \%(\mathrm{w} / \mathrm{v}) \mathrm{BSA}$.

\section{$\underline{\text { Cell and Tissue Fractionation }}$}

Solutions:

1. Homogenization buffer (deoxygenized)

$150 \mathrm{mM} \mathrm{NaCl}$

5 mM EDTA

5 mM EGTA

$50 \mathrm{mM}$ Hepes, $\mathrm{pH} 7.5$

protease inhibitor cocktail (Sigma)

2. Solubilization buffer (deoxygenized)

Homogenization buffer $+1 \%(\mathrm{v} / \mathrm{v})$ Triton X-100

Preparation of lysates:

For cultured cells

1. Pour liquid $\mathrm{N}_{2}$ in each of $10 \mathrm{~cm}$ culture dishes to pulverize cells after serum-starvation.

2. Transfer cells into the interchange and run an automatic transfer cycle.

3. Move dishes into the anaerobic chamber and add $1 \mathrm{ml}$ of ice-cold homogenization buffer for each $10 \mathrm{~cm}$ culture dish after liquid $\mathrm{N}_{2}$ is evaporated.

4. Harvest cells with cell lifter and transfer cells in $1.5 \mathrm{ml}$ Eppendorf tube.

5. Cells were sonicated briefly inside the anaerobic chamber.

Fractionation procedures

1. The cell and tissue lysates were transferred into centrifuge tubes with air-tight lids and centrifuged at $100,000 \times \mathrm{g}$ for 45 $\min$ at $4^{\circ} \mathrm{C}$.

2. Transfer tubes into the chamber and save the supernatants as the cytosol fractions.

3. The pellets were incubated in solubilization buffer on ice for $45 \mathrm{~min}$.

4. Centrifuge at $15,000 \mathrm{x}$ g for $20 \mathrm{~min}$ at $4^{\circ} \mathrm{C}$.

5. Transfer tubes into the chamber and save the supernatants as the soluble particulate fractions.

6. Protein was measured using the method of Bradford.

\section{Immunoprecipitation of PTP1B}

1. Working within the chamber, take $500 \mu \mathrm{g}$ protein of whole cell lysates or fractionations and normalize into $1 \mu \mathrm{g} / \mu \mathrm{l}$ in 0.5 $\mathrm{ml}$ in $2 \mathrm{ml}$ tubes with air-tight O-ring sealed lids (Fisher Scientific, catalog \#05-669-4). 
2. Add $2 \mu \mathrm{l}$ of non-immune IgG and $20 \mu \mathrm{l}$ of trisacryl protein $\mathrm{G}\left(50 \%\right.$ beads) for pre-clearing and incubate at $4{ }^{\circ} \mathrm{C}$ with rolling for 1 hour.

3. Briefly spin down the beads and transfer the samples back into the chamber.

4. Transfer the supernatants into a set of fresh tubes and add $2 \mu \mathrm{g}$ of anti-PTP1B antibody (Ab-2, Oncogene Sciences), a monoclonal antibody directed at a $\mathrm{C}$-terminal epitope of the enzyme that preserves its enzymatic activity.

5. Incubate at $4^{\circ} \mathrm{C}$ with rolling overnight.

6. Transfer samples into the chamber and add $50 \mu$ of trisacryl protein $\mathrm{G}$.

7. Continue to incubate at $4^{\circ} \mathrm{C}$ with rolling for two hours.

8. Centrifuge briefly and remove supernatants in the chamber.

9. Wash beads with ice-cold PBS three times and the sample are ready for PTP-1B activity assay by pNPP method.

\section{$\underline{\text { PTPase Enzyme Activity Using pNPP as Substrate }}$}

Solution:

Reaction buffer (deoxygenized):

$10 \mathrm{mM}$ of para-nitrophenylphosphate (pNPP, sigma)

2 mM EDTA

$20 \mathrm{mM}$ 2-(N-Morpholino) ethanesulfonic acid (MES) at $\mathrm{pH}$ 6.0,

1-2 mM DTT

No DTT for non-reducing reaction buffer

Stopping buffer:

$0.2 \mathrm{M} \mathrm{NaOH}$

Procedures:

1. Add reaction buffer to sample for total volume of $100 \mu \mathrm{l}$ and mix.

2. For cell lysates, incubate at $30^{\circ} \mathrm{C}$ incubator or water bath for $10 \mathrm{~min}$ to 2 hours inside the chamber. For immunoprecipitated enzymes, incubate at $37^{\circ} \mathrm{C}$ incubator or water bath for $10 \mathrm{~min}$ to 2 hours inside the chamber.

3. Terminate the reaction by adding $900 \mu$ of stopping buffer.

4. The absorption was determined at $410 \mathrm{~nm}$.

5. The initial rate of $p$ NPP hydrolysis was estimated from the linear portion of the earliest time points of the enzymatic reaction.

6. Enzyme activity is calculated from the molar extinction coefficient for phenyl phosphate $=1.78 \times 10^{4} \mathrm{M}^{-1} \mathrm{~cm}^{-1}(\mathrm{Pot}$ et al. J. Biol. Chem. 1991;266:19688-19696).

\section{PTPase Enzyme Activity Using $\left[{ }^{32} \mathrm{P}\right]-\mathrm{RCM}-\mathrm{Ly}$ sozyme as Substrate:}

Reagents:

Reduced carboxamidomethylated and maleylated (RCM) -lysozyme

partial purified recombinant human insulin receptor

$\left[\gamma-{ }^{32} \mathrm{P}\right]$ ATP $(\sim 200 \mathrm{cpm} / \mathrm{pmol})$

Solutions:

RCM-lysozyme phosphorylation buffer:

$40 \mathrm{mM}$ imidazole hydrochloride, $\mathrm{pH} 7.6$

$50 \mathrm{mM} \mathrm{NaCl}$

$12 \mathrm{mM}$ magnesium acetate

$4 \mathrm{mM} \mathrm{MnCl}{ }_{2}$

$100 \mathrm{uM}$ ammonium molybdate

$0.1 \mathrm{mM}$ Na Vanadate

$30 \mathrm{mM} \mathrm{N}$-acetylglucosamine

$0.2 \%$ deoxycholate

$0.2 \mathrm{mM}$ EGTA

Biological Procedures Online • Vol. 4 No. 1 • June 11, $2002 \cdot$ www.biologicalprocedures.com 


\author{
$0.05 \%$ Triton $\mathrm{X}-100$ \\ $3 \%$ glycerol \\ $2 \mathrm{mM}$ dithiothreitol (DTT) \\ $300 \mathrm{nM}$ insulin \\ Phosphatase assay buffer (deoxygenized): \\ $50 \mathrm{mM}$ HEPES, $\mathrm{pH} 7.0$ \\ 2 mM EDTA, \\ $25 \mathrm{mM}$ imidazole hydrochloride, $\mathrm{pH} 7.2$ \\ $1 \mathrm{mg} / \mathrm{ml}$ fatty acid- and globulin-free BSA \\ Buffer is prepared with and without added 1-2 mM DTT \\ Acidic charcoal mixture: \\ $0.9 \mathrm{M} \mathrm{NaCl}$ \\ $90 \mathrm{mM}$ sodium pyrophosphate \\ $2 \mathrm{mM} \mathrm{NaH}_{2} \mathrm{PO}_{4}$ \\ $4 \%(\mathrm{v} / \mathrm{v})$ Norit A activated charcoal
}

Procedures:

RCM-lysozyme phosphorylation (preparation of substrate):

1. Add $0.5 \mathrm{ml}$ of RCM-lysozyme phosphorylation buffer to an $1.5 \mathrm{ml}$ tube

2. Add $400 \mu \mathrm{g}$ partial purified recombinant human insulin receptor

3. Add $4 \mathrm{mM}\left[\gamma_{-}{ }^{32} \mathrm{P}\right] \mathrm{ATP}(\sim 200 \mathrm{cpm} / \mathrm{pmol})$

4. Add $1 \mathrm{mg}$ RCM-lysozyme to initiate the reaction

5. Incubate at $30^{\circ} \mathrm{C}$ overnight

6. Add $100 \%$ Trichloroacetic acid (TCA) to a final concentration of $10 \%$ to terminate reaction

7. Incubate on ice for $30 \mathrm{~min}$

8. Centrifuge at $27,000 \mathrm{x}$ g for $15 \mathrm{~min}$ at $4^{\circ} \mathrm{C}$

9. Discard the supernatant

10. Wash the protein pellet three times further with $20 \%$ TCA to remove $\left[\gamma_{-}{ }^{32} \mathrm{P}\right] \mathrm{ATP}$

11. Resuspend the pellet in $1 \mathrm{ml}$ of $2 \mathrm{M}$ Tris base, using a glass rod.

12. Leave the resuspended solution on ice overnight

13. Dialyze the sample against $50 \mathrm{mM}$ imidazole hydrochloride, $\mathrm{pH} 7.2$

14. Count $10 \mu \mathrm{l}$ of sample by Cerenkov counting in a liquid scintillation counter.

Assay of PTPases:

The assay is based on the release of $\left[{ }^{32} \mathrm{P}\right] \mathrm{Pi}$ from phosphorylated protein substrate (labeled RCM-lysozyme) and is performed in the anaerobic chamber. The initial rate of RCM-lysozyme hydrolysis was estimated from the linear portion of the earliest time points of the enzymatic reaction where less than $20 \%$ of the RCM-lysozyme was hydrolyzed. For blank control the PTPases sample is replaced by phosphatase assay buffer and the counts are less than $2 \%$ of total radioactivity in the assay.

1. Transfer samples, phosphatase assay buffer, substrate in a radioisotope-protective rack into the anaerobic chamber

2. Add $0.02 \mathrm{ml}$ samples containing $30 \mu \mathrm{g}$ proteins to $1.5 \mathrm{ml}$ centrifuge tubes

3. Add $0.02 \mathrm{ml}$ of phosphatase assay buffer

4. Preincubate at $30^{\circ} \mathrm{C}$ for $5 \mathrm{~min}$

5. Add the substrate $(>10,000 \mathrm{dpm})$

6. For cell lysates, incubate at $30^{\circ} \mathrm{C}$ for $10 \mathrm{~min}$ to 2 hours inside the chamber. For immunoprecipitated enzymes, incubate at $37^{\circ} \mathrm{C}$ for $10 \mathrm{~min}$ to 2 hours.

7. Add $0.9 \mathrm{ml}$ acidic charcoal mixture to terminate reactions

8. Transfer the reaction out of the chamber

9. Freeze briefly to facilitate the precipitation of protein

10. Thaw and centrifuge at $12,500 \mathrm{~g}$ for $5 \mathrm{~min}$

11. The amount of radioactivity in $0.4 \mathrm{ml}$ of supernatant was measured by Cerenkov counting in $5 \mathrm{ml}$ liquid scintillation counter.

Biological Procedures Online • Vol. 4 No. $1 ・$ June 11, 2002・www.biologicalprocedures.com 